\title{
Rare earth element and yttrium geochemistry applied to the genetic study of cryolite ore at the Pitinga Mine (Amazon, Brazil)
}

\author{
ORLANDO R.R. MINUZZI ${ }^{1}$, ARTUR C. BASTOS NETO ${ }^{2}$, MILTON L.L. FORMOSO ${ }^{2}$, \\ SANDRA ANDRADE ${ }^{3}$, VALCIR A. JANASI ${ }^{3}$ and JUAN A. FLORES ${ }^{2}$ \\ ${ }^{1}$ Programa de Pós-Graduação em Geociências, PPGGEO, Instituto de Geociências, Universidade Federal do Rio Grande do Sul \\ Av. Bento Gonçalves, 9.500, 91509-900 Porto Alegre, RS, Brasil \\ ${ }^{2}$ Centro de Estudos em Petrologia e Geoquímica, Instituto de Geociências, Universidade Federal do Rio Grande do Sul \\ Av. Bento Gonçalves, 9.500, 91509-900 Porto Alegre, RS, Brasil \\ ${ }^{3}$ Instituto de Geociências, Universidade de São Paulo, Rua do Lago, 562, Cidade Universitária \\ 05508-900 São Paulo, SP, Brasil. \\ Manuscript received on August 18, 2006; accepted for publication on June 19, 2008; \\ contributed by MiLTON L.L. Formoso*
}

\begin{abstract}
This work aims at the geochemical study of Pitinga cryolite mineralization through REE and Y analyses in disseminated and massive cryolite ore deposits, as well as in fluorite occurrences. REE signatures in fluorite and cryolite are similar to those in the Madeira albite granite. The highest $\Sigma$ REE values are found in magmatic cryolite (677 to $1345 \mathrm{ppm}$ ); $\Sigma$ REE is lower in massive cryolite. Average values for the different cryolite types are $10.3 \mathrm{ppm}, 6.66 \mathrm{ppm}$ and $8.38 \mathrm{ppm}$ (for nucleated, caramel and white types, respectively). Disseminated fluorite displays higher $\Sigma$ REE values (1708 and $1526 \mathrm{ppm})$ than fluorite in late veins $(34.81 \mathrm{ppm})$. Yttrium concentration is higher in disseminated fluorite and in magmatic cryolite. The evolution of several parameters $\left(\mathrm{REE}_{\text {total }}, \mathrm{LREE} / \mathrm{HREE}, \mathrm{Y}\right)$ was followed throughout successive stages of evolution in albite granites and associated mineralization. At the end of the process, late cryolite was formed with low $\mathrm{REE}_{\text {total }}$ content. REE data indicate that the MCD was formed by, and the disseminated ore enriched by (additional formation of hydrothermal disseminated cryolite), hydrothermal fluids, residual from albite granite. The presence of tetrads is poorly defined, although nucleated, caramel and white cryolite types show evidence for tetrad effect.
\end{abstract}

Key words: cryolite, REE, Y, Pitinga, Amazonia.

\section{INTRODUCTION}

Cryolite $\left(\mathrm{Na}_{3} \mathrm{AlF}_{6}\right)$ is one of the fluorine minerals of major economic importance due to its utilization for aluminum metallurgy. However, this mineral is so rare that, until now, it had only been exploited economically in Ivigtut (Greenland), from the beginning of last century until reserve exhaustion in 1986. The Pitinga Mine, Amazon (Fig. 1), is the second case of economic cryolite deposit in the world.

\footnotetext{
* Member Academia Brasileira de Ciências Correspondence to: Dr. Artur Bastos Neto E-mail: artur.bastos@ufrgs.br
}

The Pitinga ore deposit is associated with the albite granite facies of the Madeira granite. It is a worldclass $\mathrm{Sn}$ deposit containing $\mathrm{Nb}, \mathrm{Ta}$ and cryolite as coproducts, as well as $\mathrm{Zr}$, rare-earth elements (REE), Y, $\mathrm{Li}$ and $\mathrm{U}$, which may be exploited as sub-products. Reserves of disseminated ore are 164 million tons, with average $\mathrm{Sn}$ contents of $0.14 \%, \mathrm{Nb}_{2} \mathrm{O}_{5}$ of $0.20 \%$ and $\mathrm{Ta}_{2} \mathrm{O}_{5}$ of $0.024 \%$. Cryolite mineralization occurs as disseminated ore (reserves around 110 Mtons, with $4.2 \%$ of $\mathrm{Na}_{3} \mathrm{AlF}_{6}$ ), as well as a massive cryolite deposit (MCD), with a reserve of 10 Mtons $\left(32 \%\right.$ of $\left.\mathrm{Na}_{3} \mathrm{AlF}_{6}\right)$.

The Pitinga Mine is the largest Sn producer 


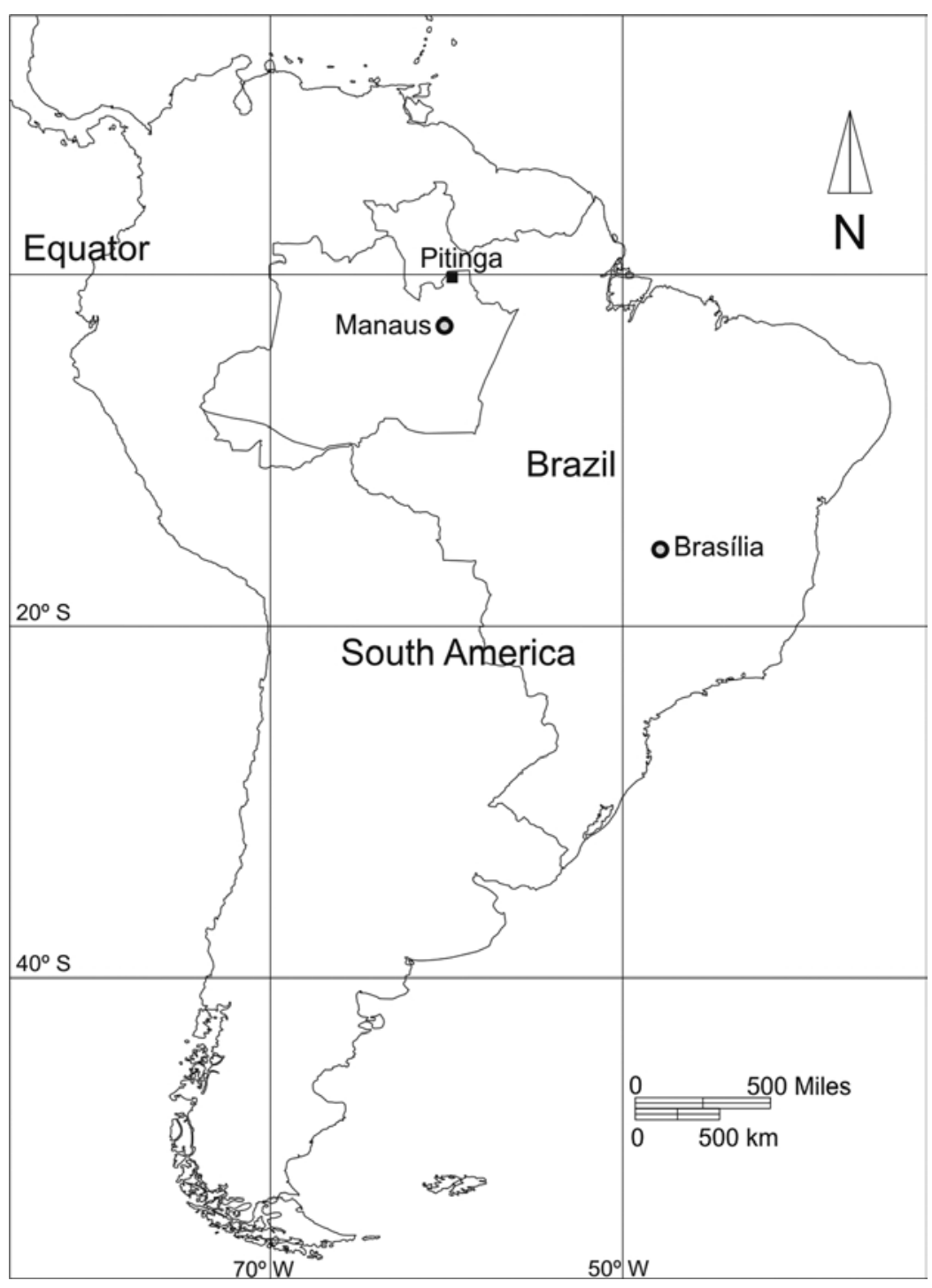

Fig. 1 - Location of the Pitinga Mine.

in Brazil. Sn exploitation initially proceeded upon the alluvial ore. Subsequently the weathered primary ore (devoid of cryolite) was exploited, and currently production is focused on cryolite-bearing ore deposits, slightly weathered or unweathered.

This work offers a contribution to a genetic model for the cryolite mineralization, based on REE and Y geochemistry in cryolite from the disseminated and massive ore types. It is a pioneer study since it considers the relationship between cryolite and fluorine with REE behavior. The REE studies were extended to fluorite, a tool to understand the hydrothermal evolution of the system, since fluorite, and not cryolite, is present in the granite border and because the relation between REE and fluorite is better constrained than REE and cryolite. REE signatures in fluorite depend on REE signatures in hydrothermal fluids.

\section{GEOLOGIC CONTEXT}

The Pitinga area is located in the southern Guyana Shield (Almeida et al. 1981). It is part of the Central Province (Tassinari and Macambira 1999), or Parimã (Santos et al. 2000). Most of the Pitinga area (Fig. 2) comprises 


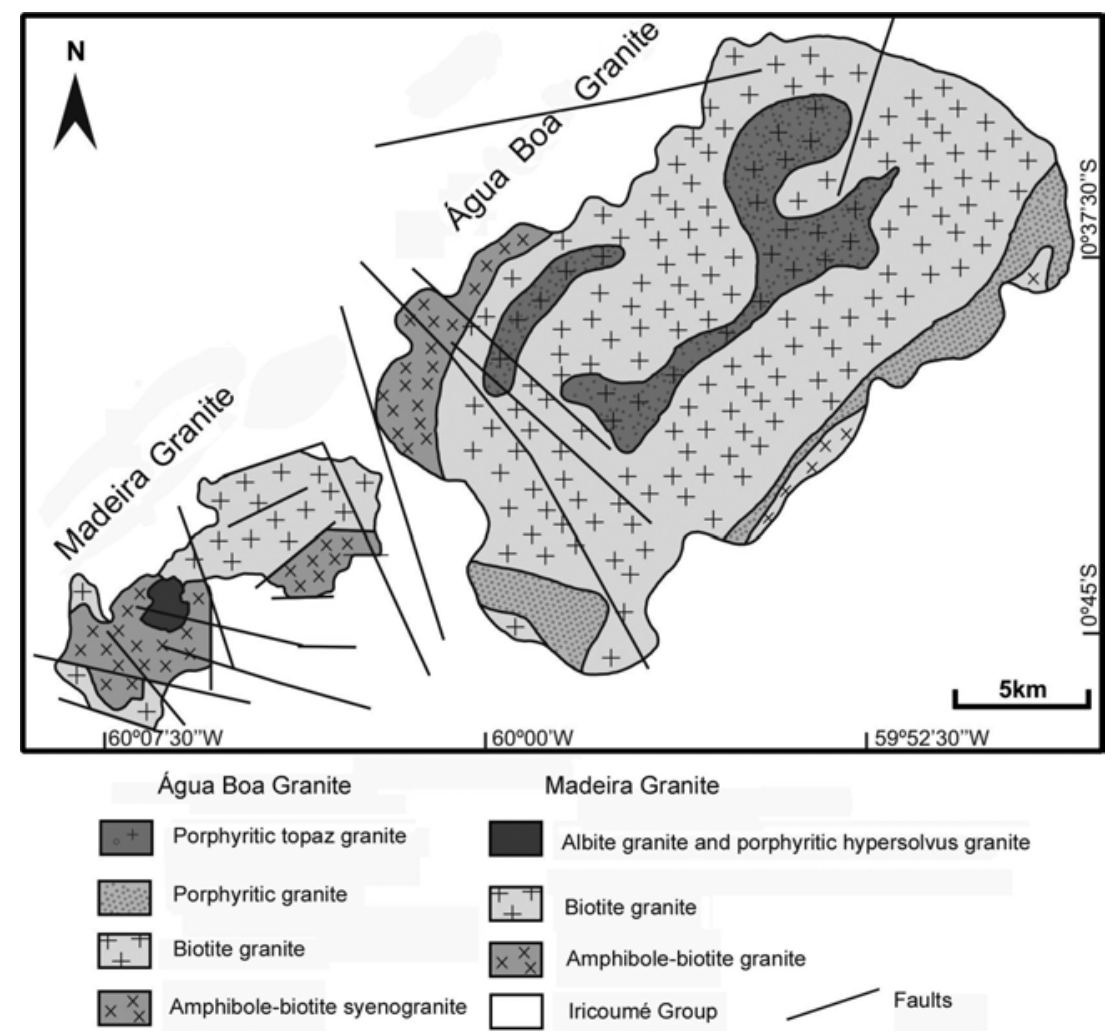

Fig. 2 - Geologic map of the Madeira and Água Boa granites, modified from Costi (2000).

acid volcanic and pyroclastic rocks from the Iricoumé Group, with zircon ${ }^{207} \mathrm{~Pb} /{ }^{206} \mathrm{~Pb}$ age of $1888 \pm 3 \mathrm{Ma}$ (Costi 2000). Two age groups of A-type granites intrude the Iricoumé Group. The granite bodies of the Mapuera suite are associated to Iricoumé volcanic rocks and display similar ages (Ferron et al. 2006). The latter Madeira and Água Boa multi-phase intrusive bodies of the Madeira Suite (Costi et al. 2000) stand out for bearing primary $\mathrm{Sn}$ ore. Costi (2000) divided the Madeira granite into four facies (Fig. 2) and determined their zircon ${ }^{207} \mathrm{~Pb} /{ }^{206} \mathrm{~Pb}$ ages: a) amphibole-biotite syenogranite (RK) (1824 \pm 2 $\mathrm{Ma})$, b) biotite-K feldspar granite (BG) $(1822 \pm 2 \mathrm{Ma})$, c) porphyritic hypersolvus $\mathrm{K}$ feldspar granite (HG) $(1818 \pm 2 \mathrm{Ma})$ and d) albite granite (Fig. 3). Though no zircon age has been obtained for the albite granite, it is considered as co-magmatic to the hypersolvus granite facies, based on field and geochemical criteria (Lenharo 1998, Costi 2000).

The core albite granite (CAG) is a subsolvus granite, with porphyritic to seriate texture, fine to medium grain size, and greyish color. It is composed chiefly of quartz, albite and alkali feldspar, of subordinately by cryolite, zircon, polythionite, riebeckite, pyrochlore, iron-rich mica, cassiterite and magnetite. Along the contact between the albite granite and the host rocks occurs the border albite granite (BAG). The latter is peraluminous and comprises essentially quartz, potassium feldspar and albite, with fluorite, zircon, chlorite, cassiterite, hematite and columbite. Modal proportions of essential phases vary. The BAG displays an increase in quartz and decrease in albite content in relation to the CAG. The CAB-BAG contact is gradual. Locally, a transitional subfacies (TAG) is well developed. The BAG is interpreted by Costi (2000) as derived from auto-metasomatism of the CAG, the latter having its peralkaline mineralogy modified by the action of residual fluids.

\section{THE CRYOLITE MINERALIZATION}

Disseminated cryolite in the CAG occurs in several forms (Fig. 4). As inclusions, forming circular to hexagonal sequences in quartz phenocrysts (snow ball tex- 


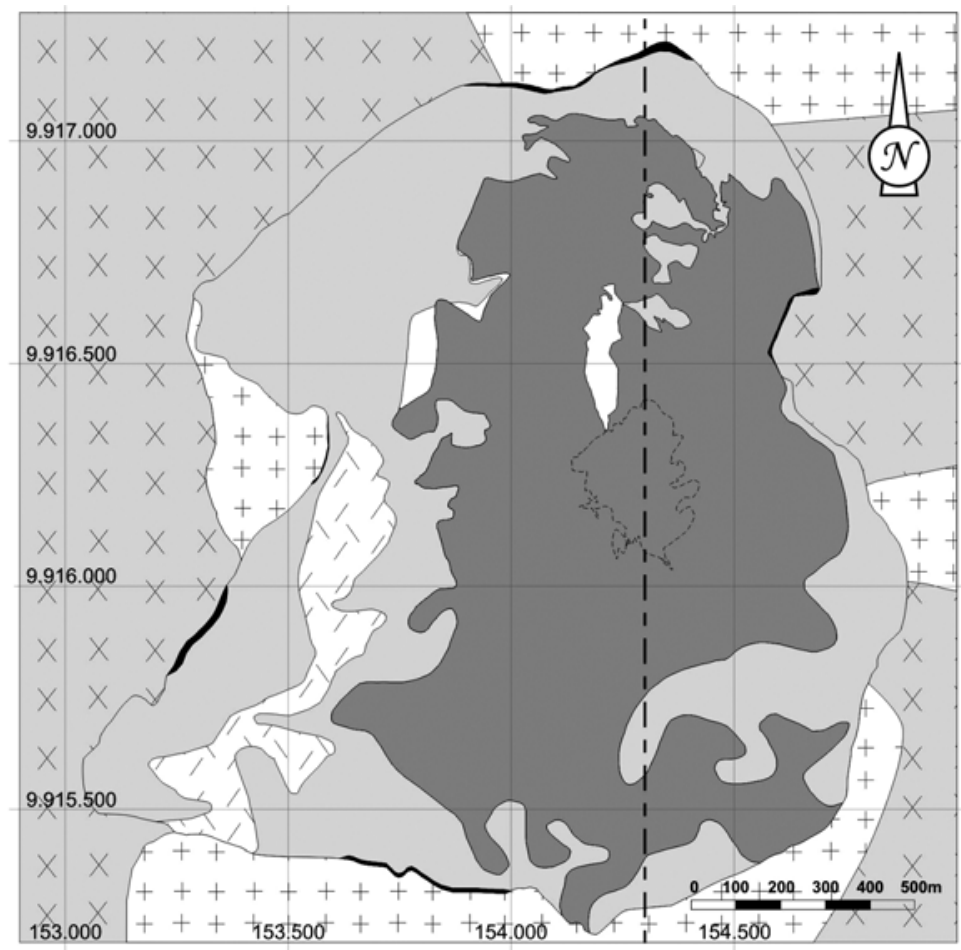

Greisen

Border Albite Granite (BAG)

Transitional Albite Granite (TAG)

Core Albite Granite (CAG)

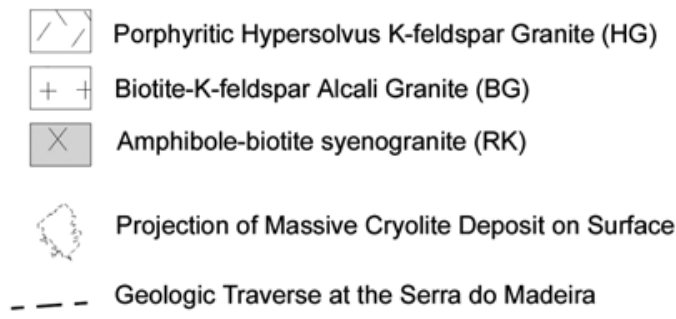

Fig. 3 - Geologic map of the albite granite facies in the Madeira granite (Minuzzi et al. 2006).

ture), and interstitial, within the CAG matrix. These features have been interpreted as evidence of rapid crystallization, contemporaneous to the phenocrysts and continuous into the subsequent matrix formation (Lenharo 1998). Costi (2000) reported that most often crystals are fine- to medium-grained, anhedral and rounded, disseminated within the matrix of porphyritic rocks, or intergrown with albite in the finest grain-size fraction of rocks with seriate texture, with straight to concave-convex boundaries with albite and K-feldspar. This suggests early crystallization and paragenetic stability. All these cryolite types were considered as magmatic cryolite. This author also described the presence of isolated crystals forming irregular to round aggregates, medium- to fine-grained, associated with other minerals related to the final stages of crystallization.

Minuzzi et al. (2006) corroborated the previous descriptions, emphasizing that, in the CAG around the Massive Cryolite Deposit (MCD) (Fig. 4), disseminated cryolite is particularly more abundant as agglomerates with white mica, zircon and quartz, and as aureoles around magmatic and pyrochlore, displaying reaction rims with these minerals. The latter two cryolite types have been considered post-magmatic, related to a hydrothermal stage.

The MCD (Minuzzi et al. 2006) displays a lenticular "mushroom" morphology, sitting at the apical zone of the albite granite along its central vertical axis. It 

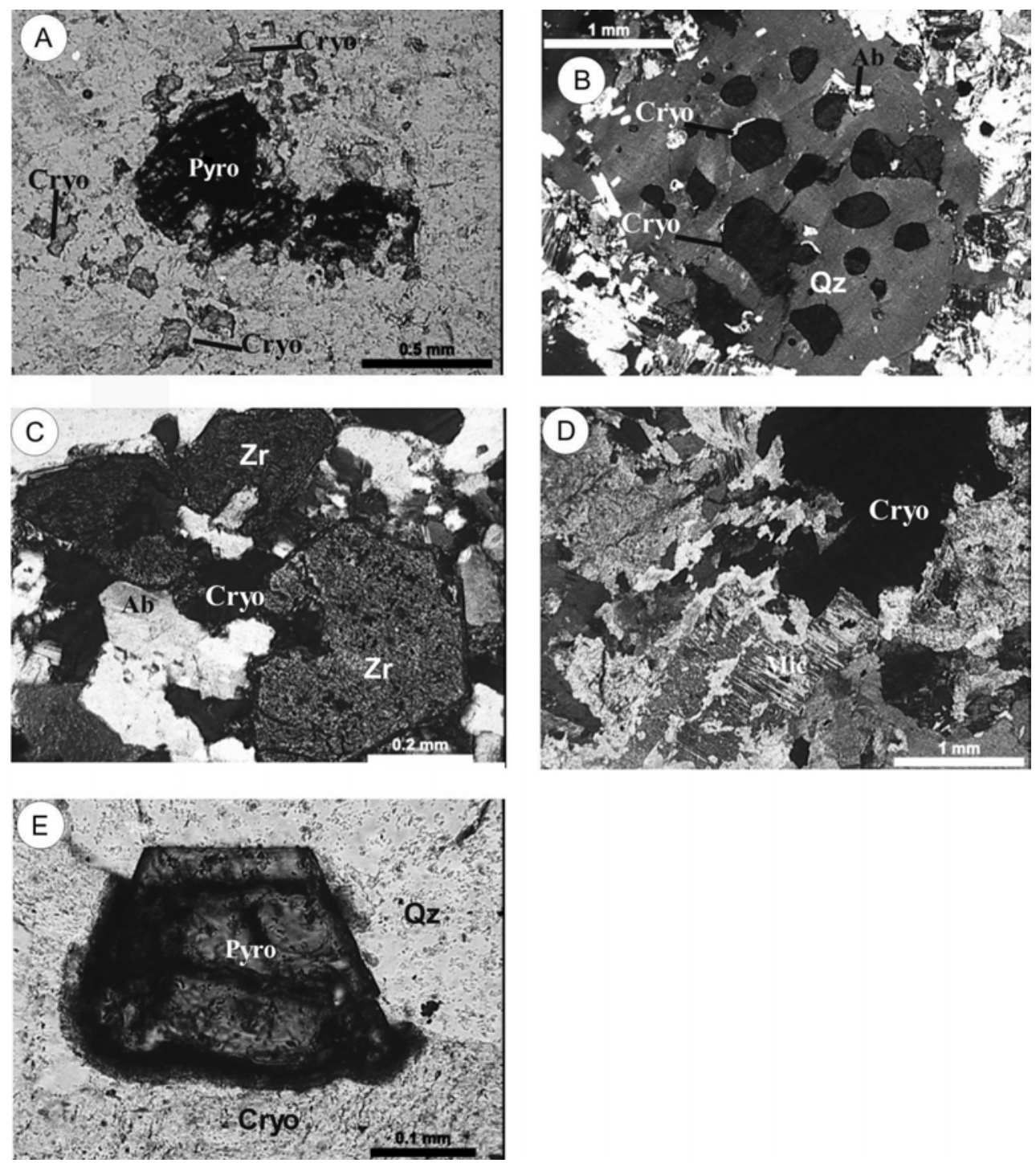

Fig. 4 - Photomicrographs of the core albite granite in the Massive Cryolite Deposit zone. (A) Magmatic pyrochlore corroded by hydrothermal cryolite, polarized light; (B) Quartz phenocryst with ovoidal cryolite, albite and matrix, crossed polars; (C) Reaction contact between magmatic zircon and hydrothermal cryolite, crossed polars; (D) Interfingered cryolite-mica aggregates, crossed polars; (E) U-Pb pyrochlore crystal showing straight contact with quartz and reaction contact with cryolite, polarized light. Symbols: (Ab) albite, (Cry) cryolite, (Mic) mica, (Pyr) pyrochlore, (Qtz) quartz, (Zrn) zircon.

is composed of sub-horizontal cryolite bodies (besides cryolite veins and stockwork) intercalated with CAG. Sub-horizontal cryolite bodies are about $300 \mathrm{~m}$ long and up to $30 \mathrm{~m}$ thick and are concentrated into two zones: Zone $\mathrm{A}$ and Zone B, $115 \mathrm{~m}$ thick and $150 \mathrm{~m}$ thick, respectively. A third, more superficial zone (zero zone) probably existed, but has been almost completely removed by erosion. The cryolite bodies comprise essentially cryolite (approximately $85 \%$ by volume), with size up to
$1.5 \mathrm{~mm}$, normally twinned crystals. Cryolite deposition proceeded initially by nucleated cryolite, followed by caramel and white cryolite. Quartz, zircon and alkali feldspar make up about 15 volume $\%$ of the bodies. These minerals have sizes of up to $1.5 \mathrm{~mm}$. Galena, xenotime and gagarinite-(Y), $\mathrm{Na}_{0,24} \mathrm{Ca}_{0,58} \mathrm{Y}_{1,01} \mathrm{REE}_{0,39} \mathrm{~F}_{5,81}$ (Pires et al. 2006) are commonly associated with the massive cryolite bodies, although the latter two minerals appear to have formed earlier than cryolite. 


\section{MATERIALS AND METHODS}

Separation of disseminated cryolite and fluorite was carried out in rock samples. Petrographic studies identified two CAG samples with predominantly magmatic cryolite, and three samples with predominantly late, disseminated cryolite. In the case of BAG, where primary paragenesis was largely replaced by a secondary paragenesis (Costi 2000), it was not possible to distinguish between primary and secondary fluorite. Hence selected samples were those with the highest mineral content. Sampling was carried out in drill cores, taking into account the presence of three types of cryolite (nucleated, caramel and white cryolite).

Samples were crushed and powdered to a grain size smaller than $0.297 \mathrm{~mm}$. Three grain size fractions $(0.178 \mathrm{~mm}, 0.131 \mathrm{~mm}$ and $0.089 \mathrm{~mm})$ were obtained through sieving. The fraction greater than $0.131 \mathrm{~mm}$ was used for dense-medium separation with LST (lithium heteropolytungstates). The concentrates were processed with a Frantz isodynamic separator and subsequently separated manually with the aid of a binocular microscope.

Ca. $100 \mathrm{mg}$ of the cryolite and fluorite sample were solubilized by acid attack $(5 \mathrm{~mL}$ deionized water $+5 \mathrm{~mL}$ sub-boiling distilled $\mathrm{HNO}_{3}$ and $10 \mathrm{~mL}$ subboiling distilled HF) in a microwave oven for 1 hour at $120^{\circ} \mathrm{C}$ and $100 \mathrm{Psi}$. In the next step, HF was eliminated by heating in a closed system using a mixture of $5 \mathrm{~mL} 85 \% \mathrm{H}_{3} \mathrm{PO}_{4}$ and $5 \mathrm{~mL} \mathrm{HNO}_{3}$. The material was then redisolved with $5 \mathrm{~mL} \mathrm{HNO}_{3}$ and diluted to a final weigh of $50 \mathrm{~g}$ with deionized water immediately before analysis. For some cryolite sample with lower total masses between 10 and $30 \mathrm{mg}$, the same procedure was adopted, and the final dilution maintained the same solid to liquis ratio. The analyses were carried out by ICP-MS in a Perkin Elmer/Sciex ELAN 6100 DRC equipment at the Instituto de Geociências, Universidade de São Paulo, Brazil. Calibration curves were constructed using reference materials BE-N, DR-N, OU-1, OU-2 and JA-1; drift correction was applied by monitoring the variation of the signal of reference material BR. Analytical quality control was assessed by analyses of reference material MRG-1, blanks and replicate sample. Corrections were made for oxide interferences on ${ }^{151} \mathrm{Eu}\left({ }^{151} \mathrm{BaO}\right),{ }^{159} \mathrm{~Tb}\left({ }^{159} \mathrm{Nd}\right.$ and $\left.{ }^{159} \mathrm{PrO}\right),{ }^{161} \mathrm{Dy}$ $\left({ }^{161} \mathrm{NdO}\right),{ }^{166} \mathrm{Er}\left({ }^{166} \mathrm{SmO}\right.$ and $\left.{ }^{166} \mathrm{NdO}\right),{ }^{169} \mathrm{Tm}\left({ }^{169} \mathrm{EuO}\right)$ and ${ }^{175} \mathrm{Lu}\left({ }^{175} \mathrm{GdO}\right)$.

Analyses of REE and Y in bulk rock samples were performed at Lakefield - Geosol Lab in Belo Horizonte, Minas Gerais State (Brazil), by ICP-OES method - following multi-acid digestion. Specific ion method was used for $\mathrm{F}$ determination. REE results were normalized to $\mathrm{C}-1$ chondrite (Anders and Grevesse 1989).

\section{RESULTS}

REE IN GRANitic FACIES (MAdEIRA GRANite)

Total REE values in the Madeira Granite (Table I) is extremely variable, between 7.6 and 1028 ppm, considering the results presented here and the analytical results provided by Lenharo (1998) and Costi (2000).

Comparing the REE distribution patterns (Fig. 5), BG, RK and HG facies are relatively enriched in REE. RK has strongly fractionated REE patterns and positive fractionation between MREE and HREE. This is in sharp contrast with biotite granite $\mathrm{BG}$, in which $\mathrm{Gd} / \mathrm{Yb}$ is $\sim 1, \mathrm{La} / \mathrm{Yb}$ is much lower, there is strong variation in HREE contents and some patterns ten to "seagull wing". The CAG exhibits a negative anomaly of $Y$ if we compare with Dy and Ho. CAG subfacies displays $\Sigma$ REE values between 7 and 838 ppm, with a relative enrichment in HREE, and a "seagull wing" pattern. The main difference between CAG and BT-KF is that the first is depleted in the LREE. REE patterns of TAG and BAG are varied. Four samples (PMR-7A, 8, 10 and 18) are particularly depleted. The other three have REE patterns do not differ too much from the CAG and are similar to BAG patterns presented by Costi (2000).

An Eu negative anomaly characterizes all granitic facies, though it is more intense in albite granites, probably because they represent facies that have undergone a higher degree of evolution with presence of a larger volatile contents. The core albite granite (CAG) has, in general, higher fluorine content than the border albite granite (BAG), what suggests a larger volatile content in the former.

\section{REE AND Y IN DIFFERENT CRYOLITE TYPES}

In order to identify possible influences of other minerals, especially zircon and pyrochlore, as inclusions in cryolite, $\mathrm{Zr}$ and $\mathrm{Nb}$ were also analyzed. Such influence 


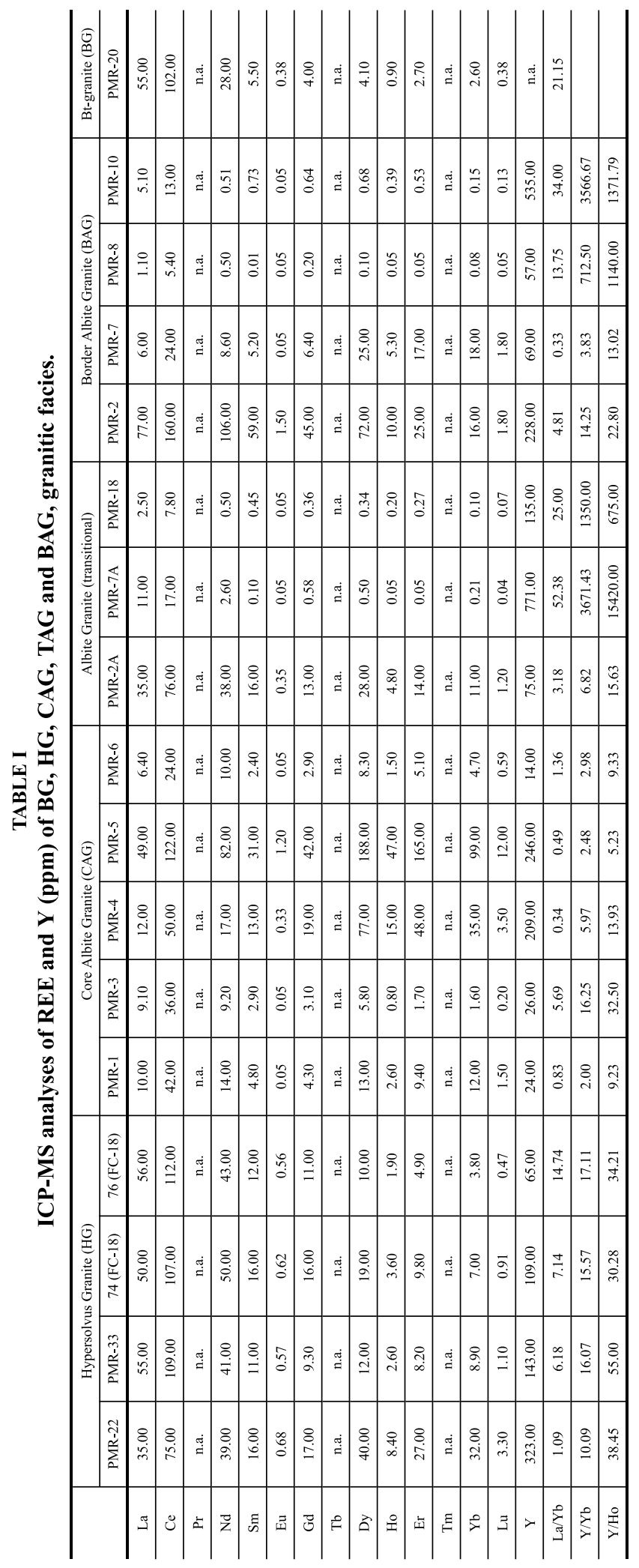


BG

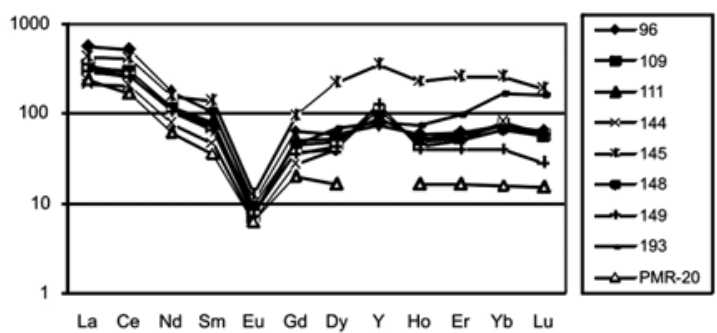

HG

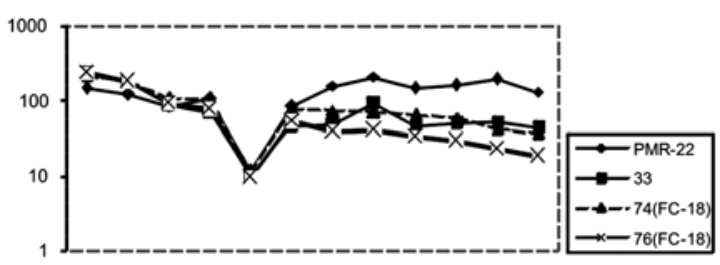

La Ce Nd Sm Eu Gd Dy Y Ho Er Yb Lu

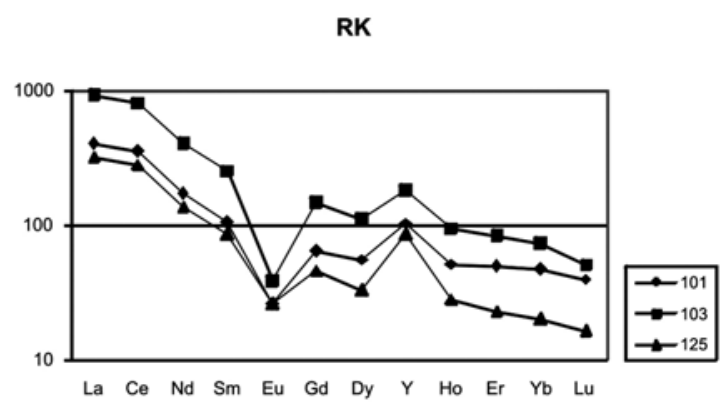

CAG

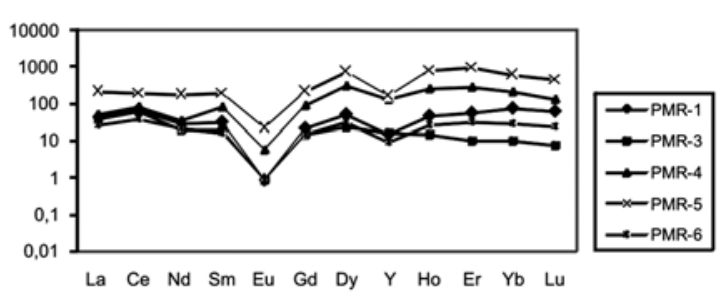

BAG

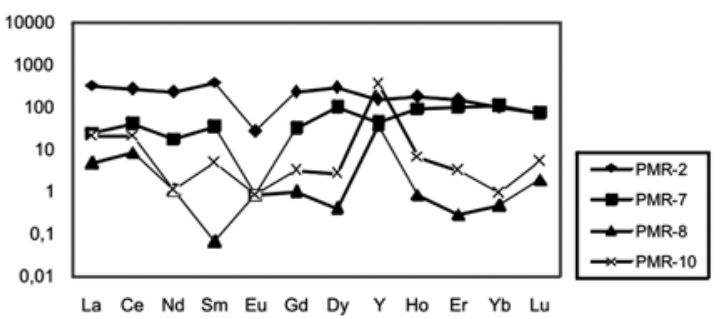

Fig. 5 - C1 chondrite-normalized REE patterns of the Madeira granite facies. A: (BG) biotite alkali feldspar granite (data from Costi 2000); B: (RK) amphibole-biotite syenogranite (data from Costi 2000); C: (HG) porphyritic hipersolvus granite subfacies; D: (CAG) core albite granite; E: (TAG) transitional albite granite subfacies; F: (BAG) border albite granite subfácies.

seems to be relatively important only in disseminated hydrothermal cryolite samples.

The diverse total REE values for disseminated cryolite samples (Table II) indicate the existence of two groups: the first one, with higher REE content (677 ppm to $1345 \mathrm{ppm}$ ), corresponds to magmatic cryolite. The second, with much lower values (29 ppm to $45 \mathrm{ppm}$ ), comprises samples of hydrothermal disseminated cryolite. MCD cryolite displays very low total REE values (Table III). Average values are $10.3 \mathrm{ppm}, 6.66 \mathrm{ppm}$ and $8.38 \mathrm{ppm}$ for the nucleated, caramel and white types, respectively. The largest total REE value (16.81 ppm) was obtained in nucleated cryolite.

REE patterns of the disseminated cryolite (Fig. 6) are similar to those from the core albite granite (CAG) (Fig. 5), which indicate genetic relationship. Cryolite displays a progressive HREE depletion from hydrothermal disseminated to white cryolite. Tetrad effects may be observed in the nucleated, caramel and white cryolite types, especially in the first tetrad. The tetrad effects are probable related to the different complex formation of REE and F (Irber 1999).

Disseminated and nucleated cryolites have almost constant LREE (Fig. 6), increasing in HREE and conspicuous negative Eu anomaly. Caramel cryolites exhibit a slight irregular decrease in LREE related to tetrad effect and an increase in HREE with also an irregular behavior, specially in sample $8 \mathrm{E}$ (FC-34), which 
TABLE II

ICP-MS analyses of REE and Y (ppm) of disseminated cryolite, disseminated fluorite and veinlet fluorite.

\begin{tabular}{|c|c|c|c|c|c|c|c|c|c|c|c|}
\hline & \multicolumn{5}{|c|}{ Disseminated cryolite } & \multicolumn{5}{|c|}{ Disseminated fluorite } & \multirow{3}{*}{$\begin{array}{c}\begin{array}{c}\text { Fluorite } \\
\text { veinlet }\end{array} \\
\text { VF-1 } \\
\end{array}$} \\
\hline & \multicolumn{2}{|c|}{ magmatic } & \multicolumn{3}{|c|}{ hydrothermal } & \multicolumn{2}{|c|}{ magmatic } & \multicolumn{3}{|c|}{ hydrothermal } & \\
\hline & PMR-4 & PMR-5 & PMR-1 & PMR-3 & PMR-6 & PMR-7A & PMR-10 & PMR-2 & PMR-7 & PMR-9 & \\
\hline $\mathrm{La}$ & 24.37 & 42.88 & 2.96 & 2.05 & 1.83 & 171.17 & 125.76 & 67.84 & 13.84 & 9.72 & 2.26 \\
\hline $\mathrm{Ce}$ & 39.17 & 98.34 & 4.17 & 3.78 & 3.76 & 561.31 & 471.41 & 155.95 & 49.69 & 33.16 & 6.40 \\
\hline $\operatorname{Pr}$ & 9.55 & 21.75 & 0.70 & 0.52 & 0.70 & 82.67 & 68.88 & 35.28 & 6.74 & 5.01 & 0.77 \\
\hline $\mathrm{Nd}$ & 31.55 & 77.56 & 3.47 & 2.68 & 3.51 & 290.29 & 234.83 & 110.40 & 19.45 & 11.55 & 3.15 \\
\hline $\mathrm{Sm}$ & 17.15 & 25.85 & 1.25 & 0.93 & 1.17 & 123.53 & 93.44 & 63.43 & 9.78 & 7.93 & 1.00 \\
\hline $\mathrm{Eu}$ & 0.50 & 0.93 & 0.05 & 0.03 & 0.05 & 2.31 & 1.63 & 1.38 & 0.18 & 0.15 & 0.03 \\
\hline $\mathrm{Gd}$ & 25.05 & 39.80 & 1.71 & 0.96 & 1.54 & n.d. & n.d. & 48.98 & n.d. & n.d. & 2.06 \\
\hline $\mathrm{Tb}$ & 14.23 & 22.48 & 0.74 & 0.36 & 0.50 & 35.17 & 31.49 & 16.64 & 2.87 & 2.49 & 0.39 \\
\hline Dy & 145.67 & 260.20 & 6.91 & 3.29 & 4.15 & 245.30 & 254.08 & 102.09 & 24.83 & 18.53 & 3.22 \\
\hline Ho & 46.75 & 89.11 & 1.97 & 0.92 & 1.39 & 45.24 & 55.33 & 18.31 & 6.54 & 4.08 & 1.06 \\
\hline $\mathrm{Er}$ & 161.99 & 316.66 & 7.37 & 4.72 & 4.51 & 117.03 & 152.03 & 41.39 & 24.69 & 12.13 & 3.14 \\
\hline $\mathrm{Tm}$ & 27.54 & 56.01 & 1.69 & 1.12 & 0.87 & 19.78 & 23.83 & 5.74 & 5.60 & 2.23 & 0.51 \\
\hline $\mathrm{Yb}$ & 112.94 & 246.23 & 10.44 & 7.14 & 4.84 & n.d. & n.d. & 27.25 & n.d. & n.d. & 4.29 \\
\hline $\mathrm{Lu}$ & 21.44 & 47.53 & 2.01 & 1.38 & 0.89 & 15.14 & 14.10 & 3.71 & 6.22 & 1.94 & 0.39 \\
\hline $\mathrm{Y}$ & 188.83 & 209.55 & 34.37 & 18.12 & 14.98 & 1435.83 & 1209.77 & 186.71 & 217.86 & 196.39 & 34.81 \\
\hline $\mathrm{Eu} / \mathrm{Eu}^{*}$ & 0.07 & 0.09 & 0.09 & 0.11 & 0.10 & & & 0.07 & & & 0.07 \\
\hline $\mathrm{La} / \mathrm{Yb}$ & 0.22 & 0.17 & 0.28 & 0.29 & 0.38 & & & 2.49 & & & 0.53 \\
\hline $\mathrm{La} / \mathrm{Sm}$ & 1.42 & 1.66 & 2.37 & 2.20 & 1.56 & 1.39 & 1.35 & 1.07 & 1.42 & 1.23 & 2.26 \\
\hline $\mathrm{La} / \mathrm{Lu}$ & 1.14 & 0.90 & 1.47 & 1.48 & 2.06 & 11.31 & 8.92 & 18.27 & 2.23 & 5.00 & 5.84 \\
\hline $\mathrm{Gd} / \mathrm{Yb}$ & 0.22 & 0.16 & 0.16 & 0.13 & 0.32 & & & 1.80 & & & 0.48 \\
\hline$\Sigma$ LREE & 121.80 & 266.37 & 12.54 & 9.96 & 10.96 & 1228.97 & 994.32 & 432.90 & 99.50 & 67.37 & 13.57 \\
\hline$\Sigma$ HRRE & 555.61 & 1078.01 & 32.83 & 19.88 & 18.69 & 477.66 & 530.86 & 264.10 & 70.74 & 41.40 & 15.07 \\
\hline$\Sigma$ RRE & 677.91 & 1345.31 & 45.42 & 29.87 & 29.69 & 1708.95 & 1526.81 & 698.38 & 170.42 & 108.92 & 28.67 \\
\hline LRRE/HRRE & 0.22 & 0.25 & 0.38 & 0.50 & 0.59 & 2.57 & 1.87 & 1.64 & 1.41 & 1.63 & 0.90 \\
\hline
\end{tabular}

shows a unique pattern including a positive anomaly of ytterbium. The white cryolites (just two samples) also display positive anomaly of ytterbium, but have different behaviors in respect to LREE: One 7CA (FC-12) shows constant LREE and the other 7C (FE-12) reveals irregular shape of LREE.

The unique pattern of HREE and positive ytterbium anomalies are probably related to tetrad effects in caramel and white cryolite. We inserted Y patterns between Dy and Ho according to Bau and Dulski (1995). It is observed in disseminated cryolite a high negative $\mathrm{Y}$ anomaly relative to Dy and Ho. Caramel and white cryolites also display the same behavior. Y and Ho have ionic charge and radius very similar but the electronic configurations are quite different justifying the dissimilar behavior of these anions in presence of some ligands as $\mathrm{F}$.

Hydrothermal disseminated cryolite is characterized by calculated Eu anomaly $(\sim 0.09)$ as pronounced as in magmatic cryolite (Table II). The three cryolite generations in MCD display Eu anomalies systematically less pronounced $(\sim 0.16)$.

Some REE parameters show an evolution from the magmatic environment throughout low-temperature hydrothermal conditions. $\mathrm{REE}_{\text {total }}$ fractionation $(\mathrm{La} / \mathrm{Lu})$, increasing towards late cryolite, is conspicuous: magmatic cryolite ( 0.90 to 1.14$)$, disseminated hydrothermal cryolite (1.47 to 2.06 ), nucleated cryolite (1.61 to 5.40), caramel cryolite (5.67 to 17.41 ) and white cryolite (12.13 to 218.60). The evolution of LREE/HREE ratios displays relative impoverishment in HREE: from magmatic cryolite ( 0.22 to 0.25 ), hydrothermal disseminated cryolite ( 0.38 to 0.59$)$, to zoned cryolite $(0.50$ $2.28)$, caramel cryolite (1.84-10.86), and finally white cryolite (3.13-13.59).

Magmatic cryolite displays Y contents (Fig. 7a) around $200 \mathrm{ppm}$; late disseminated cryolite varies between 15 and $34 \mathrm{ppm}$. Apparently there is a gradual 
TABLE III

ICP-MS analyses of REE and Y (ppm) of massive cryolite (nucleated, caramel and white types).

\begin{tabular}{|c|c|c|c|c|c|c|c|c|c|c|c|c|}
\hline & \multicolumn{12}{|c|}{ Massive cryolite deposit } \\
\hline & \multicolumn{4}{|c|}{ Nucleated cryolite } & \multicolumn{4}{|c|}{ Caramel cryolite } & \multicolumn{4}{|c|}{ White cryolite } \\
\hline & $4 \mathrm{I}$ & $13 \mathrm{E}$ & $21 \mathrm{~B}$ & $25 \mathrm{~B}$ & $34 \mathrm{C}$ & $38 \mathrm{~B}$ & $7 \mathrm{~B}$ & $8 \mathrm{E}$ & $18 \mathrm{D}$ & $40 \mathrm{C}$ & $7 \mathrm{CA}$ & $7 \mathrm{C}$ \\
\hline $\mathrm{La}$ & 0.89 & 0.89 & 1.05 & 0.89 & 0.87 & 0.95 & 1.10 & 0.85 & 0.90 & 0.90 & 1.46 & 0.88 \\
\hline $\mathrm{Ce}$ & 1.33 & 1.67 & 1.99 & 1.31 & 1.26 & 1.61 & 2.65 & 1.17 & 1.46 & 1.49 & 3.53 & 1.30 \\
\hline $\operatorname{Pr}$ & 0.20 & 0.28 & 0.26 & 0.18 & 0.18 & 0.22 & 0.34 & 0.17 & 0.21 & 0.22 & 0.47 & 0.20 \\
\hline $\mathrm{Nd}$ & 1.63 & 2.04 & 1.75 & 1.52 & 1.55 & 1.67 & 1.93 & 1.49 & 1.64 & 1.68 & 2.61 & 1.63 \\
\hline $\mathrm{Sm}$ & 0.48 & 0.74 & 0.60 & 0.45 & 0.47 & 0.54 & 0.66 & 0.44 & 0.50 & 0.53 & 0.92 & 0.50 \\
\hline $\mathrm{Eu}$ & 0.02 & 0.03 & 0.03 & 0.02 & 0.02 & 0.02 & 0.02 & 0.02 & 0.02 & 0.02 & 0.03 & 0.02 \\
\hline $\mathrm{Gd}$ & 0.20 & 0.76 & 0.45 & $<0.15$ & $<0.15$ & 0.20 & 0.25 & $<0.15$ & 0.19 & 0.18 & 0.93 & $<0.15$ \\
\hline $\mathrm{Tb}$ & 0.04 & 0.33 & 0.20 & 0.02 & 0.01 & 0.07 & 0.09 & $<0.01$ & 0.04 & 0.04 & 0.19 & 0.02 \\
\hline Dy & 0.59 & 3.09 & 2.07 & 0.27 & 0.23 & 0.60 & 0.75 & 0.14 & 0.36 & 0.37 & 1.13 & 0.18 \\
\hline Ho & 0.23 & 0.80 & 0.60 & 0.11 & 0.08 & 0.19 & 0.23 & 0.03 & 0.11 & 0.10 & 0.19 & 0.03 \\
\hline $\mathrm{Er}$ & 1.08 & 2.51 & 2.15 & 0.45 & 0.35 & 0.61 & 0.77 & 0.14 & 0.37 & 0.36 & 0.39 & 0.09 \\
\hline $\mathrm{Tm}$ & 0.32 & 0.45 & 0.44 & 0.10 & 0.10 & 0.12 & 0.15 & 0.03 & 0.06 & 0.08 & 0.04 & 0.01 \\
\hline $\mathrm{Yb}$ & 2.76 & 2.75 & 2.69 & 0.79 & 0.80 & 0.78 & 1.02 & $<0.50$ & $<0.50$ & $<0.50$ & $<0.50$ & $<0.50$ \\
\hline $\mathrm{Lu}$ & 0.55 & 0.45 & 0.52 & 0.16 & 0.15 & 0.14 & 0.17 & 0.05 & 0.07 & 0.07 & 0.02 & 0.00 \\
\hline $\mathrm{Y}$ & 3.67 & 17.44 & 19.18 & 3.33 & 1.44 & 4.90 & 3.15 & 0.63 & 2.58 & 1.60 & 1.82 & 0.47 \\
\hline $\mathrm{Eu} / \mathrm{Eu}^{*}$ & 0.21 & 0.11 & 0.16 & 0.18 & 0.17 & 0.19 & 0.16 & 0.18 & 0.16 & 0.16 & 0.11 & 0.15 \\
\hline $\mathrm{La} / \mathrm{Yb}$ & 0.32 & 0.32 & 0.39 & 1.13 & 1.08 & 1.22 & 1.08 & & & & & \\
\hline $\mathrm{La} / \mathrm{Sm}$ & 1.86 & 1.21 & 1.74 & 1.98 & 1.85 & 1.78 & 1.67 & 1.92 & 1.79 & 1.71 & 1.58 & 1.77 \\
\hline $\mathrm{La} / \mathrm{Lu}$ & 1.61 & 1.97 & 2.02 & 5.40 & 5.67 & 6.93 & 6.59 & 17.41 & 13.07 & 12.13 & 93.26 & 218.60 \\
\hline $\mathrm{Gd} / \mathrm{Yb}$ & 0.07 & 0.28 & 0.17 & & & 0.25 & 0.25 & & & & & \\
\hline$\Sigma$ LREE & 4.54 & 5.63 & 5.65 & 4.36 & 4.33 & 4.98 & 6.69 & 4.13 & 4.71 & 4.82 & 8.99 & 4.52 \\
\hline$\Sigma$ HREE & 5.77 & 11.15 & 9.12 & 1.91 & 1.72 & 2.70 & 3.43 & 0.38 & 1.18 & 1.20 & 2.87 & 0.33 \\
\hline$\Sigma \mathrm{REE}$ & 10.34 & 16.81 & 14.80 & 6.28 & 6.07 & 7.71 & 10.14 & 4.53 & 5.91 & 6.04 & 11.90 & 4.87 \\
\hline LREE/HREE & 0.79 & 0.50 & 0.62 & 2.28 & 2.52 & 1.84 & 1.95 & 10.86 & 4.01 & 4.03 & 3.13 & 13.59 \\
\hline
\end{tabular}

evolution marked by decreasing $\mathrm{Y}$ concentration from late disseminated cryolite to nucleated and caramel to white cryolite (Fig. 7b).

\section{REE AND Y IN FLUORITE}

Fluorite displays a variety of $\Sigma$ REE. Fluorite with magmatic (disseminated) characteristics shows values of 1500-1700 ppm; hydrothermal disseminated fluorite of 100-700 ppm and veinlet (very late) fluorite around 28 ppm (Fig. 6). These values represent fluorite precipitation in three events, with different compositions and REE depletion in very late fluorite.

REE signature in fluorite is very similar to that of granites (CAG), with a characteristic negative Eu anomaly, in general without enrichment in heavy REE, except in veinlet fluorite, which displays a slight HREE enrichment. REE signature in fluorite is similar to that of disseminated early cryolite. The tetrad effect is not detected in fluorite.
In the case of $\mathrm{Y}$, concentrations lie along three ranges: $1200 \mathrm{ppm}$ (disseminated magmatic fluorite); $200 \mathrm{ppm}$ (hydrothermal disseminated fluorite) and $34 \mathrm{ppm}$ (late vein fluorite). Low yttrium concentrations are thus typical of late phases in both minerals (cryolite and fluorite). Fluorite show slight positive anomalies of Y except one sample (PMR-2) which presents a negative anomaly.

\section{DISCUSSION}

There are very few studies concerning genetic models for Pitinga cryolite mineralization. Most models focus either on granite petrology or on Sn mineralization. Existing genetic models for cryolite in granites include one metasomatic model (Horbe et al. 1985, Teixeira et al. 1992), which considers the albite granite an apogranite, and two different magmatic models, the first by Lenharo (1998) who suggested that the MCD was formed from a F-rich residual liquid which has become immiscible in 
Disseminated Cryolite

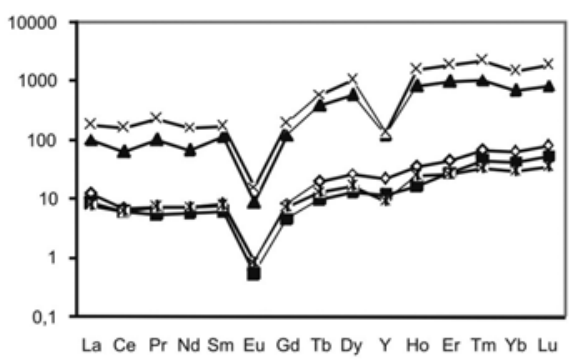

Caramel Cryolite

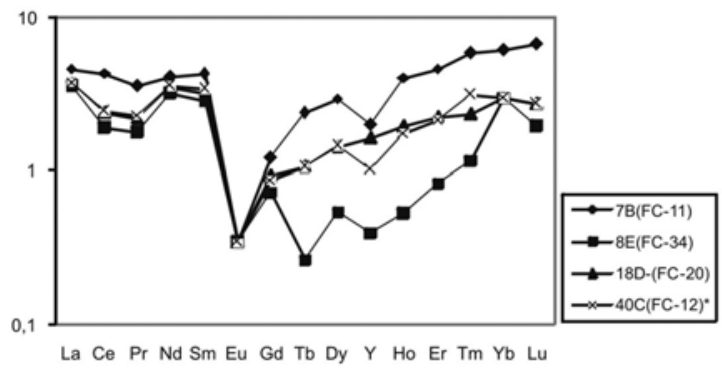

Fluorite

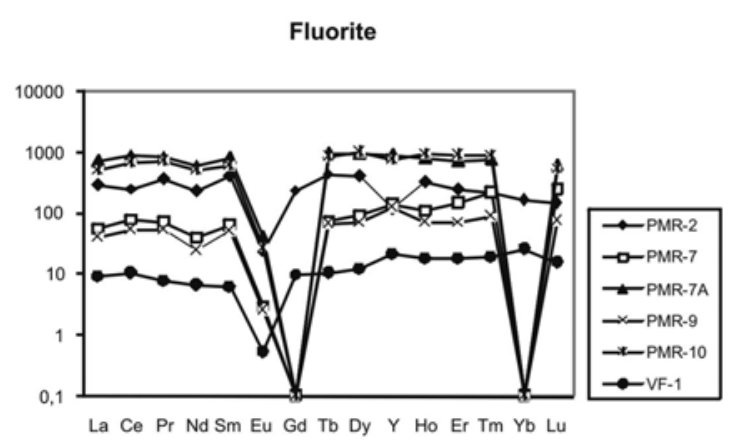

Nucleated Cryolite

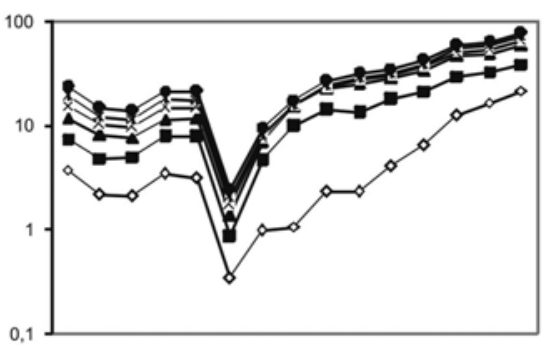

La Ce Pr Nd Sm Eu Gd Tb Dy Y Ho Er Tm Yb Lu

White Cryolite

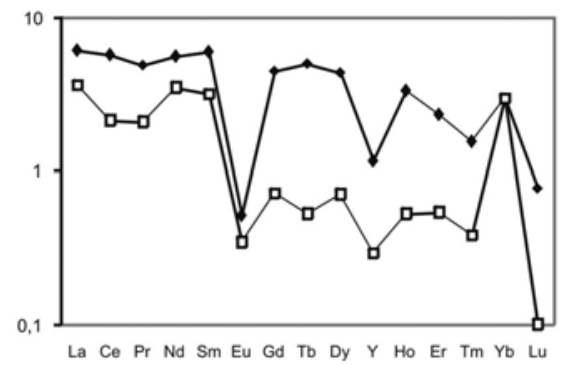

$\rightarrow-38 \mathrm{~B}(\mathrm{FC}-12)$ $\rightarrow=34 \mathrm{C}(\mathrm{FC}-12$ $-x-25 B(F C-11)$ $-21 \mathrm{~B}(\mathrm{FC}-11)$ $\rightarrow-4($ (FC-22)

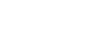

Fig. 6 - $\mathrm{C} 1$ chondrite-normalized REE patterns of disseminated cryolite, different cryolite types, disseminated fluorite and veinlet fluorite. (A) Nucleated cryolite; (B) Caramel cryolite; (C) White cryolite; (D) Disseminated cryolite; (E) Disseminated and veinlet fluorite.

the silicate liquid, and the second by Costi (2000) who considered that increasing water content as the crystallization of the albite granite progressed led to the separation of aqueous fluids responsible for the formation of coarse-grained (pegmatoid) rocks in the CAG, whereas a F-rich residual phase formed the massive cryolite bodies of the MCD.

Experimental results prior to 1980 showed that liquidus and solidus temperatures of granitic melts decrease with addition of fluorine (Tuttle and Bowen 1958, Wyllie and Tuttle 1961, Gliuk and Anfilogov 1973,
Kovalenko 1977); these were confirmed ultimately by more detailed results (Manning 1981, Pichavant and Manning 1984, Weidner and Martin 1987, Pichavant et al. 1987, Manning and Pichavant 1988, London 1989, Xiong et al. 1999). Kovalenko (1977) considers a decrease of $150^{\circ} \mathrm{C}$ in solidus temperatures under influence of high activity of $\mathrm{F}$.

At the Ivigtut granite, the presence of interstitial cryolite is considered as produced by a residual stage of the fluid that circulated freely through the interstices of nearly completely solidified granite (Blaxland 1976). 

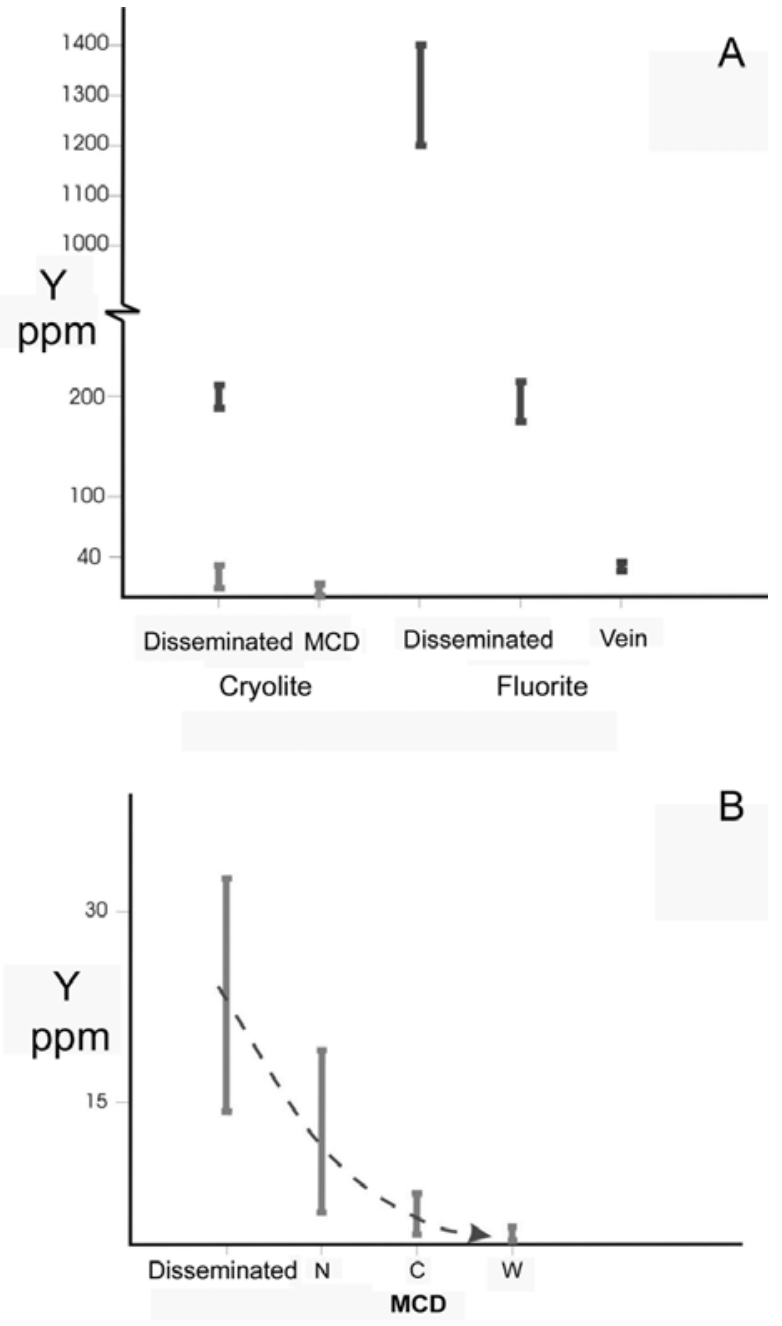

Fig. 7 - (A) Variation intervals of yttrium concentration in cryolite and fluorite samples; (B) Detail of the previous diagram, with hydrothermal disseminated cryolite and the 3 types of cryolite from the massive cryolite deposit (MCD); $\mathrm{N}=$ nucleated, $\mathrm{C}=$ Caramel, $\mathrm{W}=$ White.

Interstitial cryolite is also considered as the product of recrystallization of late stage, F-rich, pervasive hydrothermal fluids in the Nigerian anorogenic alkali granites (Bowden and Kinnaird 1984).

In the albite granite, the petrologically most evolved facies of the Madeira granite (Costi 2000), high fluorine activity allowed for formation of early (magmatic) cryolite on one hand and superposition of late and post-magmatic processes to which formation of most of the cryolite ore is related (late, disseminated cryolite and mainly cryolite from the MCD) on the other hand. The concentration of $\mathrm{F}$ in $\mathrm{CAG}$ is around
1900 ppm and certainly a parallel high activity of $\mathrm{F}$ is responsible by the formation of $\mathrm{F}^{-}, \mathrm{Al}^{3+}$ and REE complexes, especially in peralkaline granite, including the $\left[\mathrm{AlF}_{6}\right]^{-3}$, a necessary complex for the cryolite formation.

The overall behavior of REE in the facies of the Madeira granite shows a strong enrichment in HREE and greater negative $\mathrm{Eu}$ anomalies in albite granite as compared to RK, BG and HG facies. HREE enrichment relative to LREE occurs in the sequence RK, BG, HG and CAG. In the Ivigtut cryolite ore deposit, a similar behavior was observed in relation to slightly altered host rocks and albitized rocks near the cryolite deposit. This was interpreted as host-rock metasomatism, with the formation of complex ions between HREE and $\mathrm{F} \pm$ $\mathrm{Cl}$ (Pauly and Bailey 1999). In contrast with what is observed in the CAG subfacies and in Ivigtut, the cryolitebearing anorogenic alkali granites from Nigeria display enrichment in LREE, followed by a slight increase in Eu (Kinnaird et al. 1985).

At Pitinga, the REE and $\mathrm{Y}$ data agree with geological and petrographic data in the sense that MCD do not represent an exotic body within albite granites, regarding localization, shape, paragenesis or chemical composition. Thus, a metasomatic model such as Ivigtut's is not applicable to Pitinga and a magmatic-hydrothermal model is here assumed. At Pitinga, the evolution of several parameters $\left(\mathrm{REE}_{\text {total }}, \mathrm{La} / \mathrm{Lu}, \mathrm{LREE} / \mathrm{HREE}, \mathrm{Y}\right)$ was followed throughout successive stages of evolution in albite granites and associated cryolite mineralization. The evolution is marked by a depletion in REE and Y. It is a stepwise depletion in for disseminated magmatic and disseminated hydrothermal cryolites, but it is a gradual depletion from disseminated hydrothermal cryolite and MCD. At the end of the process, late cryolite was formed. Its white color is presumed to be due to the extremely low $\mathrm{REE}_{\text {total }}$ content.

Magmatic fluorite (BAG) has the same REE pattern as albite granite. Moreover, $\mathrm{Y}$ concentration ranges illustrate three generations of fluorite. A comprehensive study by Fayzigev (1990, cited by Chang et al. 1996) showed that the highest $\mathrm{Y}$ concentration in fluorite are found in pegmatite-related occurrences. Considering that albite granite was formed from a magma with pegmatitic composition (Costi 2000), Y concentrations in disseminated fluorite around $1200 \mathrm{ppm}$ (samples 
PMR7A and PMR-10) are compatible with crystallization in a magmatic environment, while samples with concentrations of $200 \mathrm{ppm}$ would be products of the hydrothermal stage. A fluorite sample from a late vein (Y $\sim 20 \mathrm{ppm}$ ) represents the final stages of hydrothermalism.

In the magmatic fluorite, REE/Y and LREE/HREE ratios are slightly above 1 , similar to the rock ratios. On the other hand, they are partly distinct from most fluorite occurrences, which display $\mathrm{Y}>\mathrm{REE}$ and LREE $>$ HREE ratios (Chang et al. 1996). Cryolite, however, shows a different behavior. Magmatic cryolite displays a more pronounced relative enrichment in REE (REE/Y 3.6 to 6.4) than fluorite $(\mathrm{REE} / \mathrm{Y} \sim 1.2)$. On the other hand, HREE > LREE ratio in magmatic cryolite (LREE/HREE 0.22 and 0.25 ) is contrary to the rock ratio. These two aspects may reflect the preferential $\mathrm{Na}$ substitution by small ionic-radii REE (Y behaves similarly to HREE), an effect that is much less pronounced in fluorite.

The systematic difference in Eu anomaly between disseminated and massive cryolite may be related to variations in the redox conditions. In fluorite, the Eu anomaly is inversely related to the mineral $\mathrm{Eu}^{2+} / \mathrm{Eu}_{\text {total }}$ ratio measured by RPE (Méary et al. 1985), which depends on the solution $\mathrm{Eu}^{2+} / \mathrm{Eu}^{3+}$ ratio; this ratio depends on $\mathrm{fO}_{2}$, for a fixed $\mathrm{pH}$ (Sverjensky 1984). $\mathrm{Eu}^{3+}$ cation, with an ionic radius smaller than $\mathrm{Eu}^{2+}$, is preferentially incorporated to replace $\mathrm{Ca}$. Hence decreasing solution $\mathrm{Eu}^{2+} / \mathrm{Eu}^{3+}$ ratio leads to less pronounced $\mathrm{Eu}$ negative anomalies. In cryolite, the preferential replacement of $\mathrm{Na}$ by small-radius REE was observed. Consequently, the relation between the variation in solution $\mathrm{Eu}^{2+} / \mathrm{Eu}^{3+}$ ratio and mineral anomaly is probably the same observed for fluorite. Therefore we suggest that the three generations of massive cryolite were formed in an environment more oxidizing than that of magmatic and disseminated hydrothermal cryolite. Disseminated hydrothermal cryolite was formed by residual fluids of magmatic origin, under redox conditions similar to those in the magmatic environment. During the formation of the MCD there was contribution from more oxidizing solutions, possibly of meteoric origin. Influx of this solution indicates opening of the system, possibly related to fracture reactivation which may imply activation of convective hydrothermal system.

\section{CONCLUSIONS}

REE signature in fluorite and cryolite are similar to those in albite granite. Cryolite and fluorite display negative Eu anomaly, inherited from and/or increased by the evolution of the granitic system. High values of HREE relative to LREE are found in albite granite as well as in disseminated and nucleated cryolite types. In fluorite and white cryolite these features are either not observed or not conspicuous. The highest values of $\Sigma$ REE are found in magmatic-hydrothermal disseminate cryolite. In massive cryolite, $\Sigma$ REE is lower (4.8 to $16.8 \mathrm{ppm}$ ). Disseminated fluorite has higher REE values than late fluorite veins. Y shows higher values in disseminated fluorite and magmatic cryolite in relation to vein fluorite and hydrothermal cryolite, respectively. The higher content of $\mathrm{F}$ in $\mathrm{CAG}$ and the peralkaline affinity of this granite seem to be responsible for the formation of complexes as $\left[\mathrm{AlF}_{3}\right]^{-3}$ which could form cryolite associated to this type of granite.

The evolution of several parameters ( $\mathrm{REE}_{\text {total }}$, LREE/HREE, Y) was followed throughout successive stages of evolution in albite granite and associated mineralization. At the end of the process, late cryolite was formed. Its white color is presumed to be due to the extremely low $\mathrm{REE}_{\text {total }}$ content. The REE and $\mathrm{Y}$ data agree with geological and petrographic data in the sense that (1) there are two types of disseminated cryolite (magmatic and hydrothermal) and (2) massive cryolite bodies do not represent an exotic body within albite granites, regarding localization, shape, paragenesis or chemical composition. Thus, a metasomatic model such as Ivigtut's is not applicable to the Pitinga albite granite or to the associated MCD. REE data indicate that the MCD was formed by, and the disseminated ore enriched by (additional formation of hydrothermal disseminated cryolite), hydrothermal fluids, residual from albite granite, that are ascendent from the lower parts of the body. During the formation of the MCD there was contribution from more oxidant solutions, even meteoric origin. Influx of this solution indicates opening of the system, possibly related to fracture reactivation which may imply activation of convective hydrothermal system.

The presence of tetrads is not well defined. Fluorite does not show tetrad effect. Neither does disseminated magmatic-hydrothermal cryolite. Nucleated, cara- 
mel and white cryolites show some evidence of tetrad effect, especially in the first tetrad. More detailed analyses shall be carried out in cryolite to investigate the tetrad effect. Among the different granites, the core albite granite $(\mathrm{CAG})$ is the facies that display signs of tetrad effect. The $\mathrm{F}$ has much influence in the presence of tetrad effects but there are also others important parameters (electronic configuration, chemical bonds, others ions as $\left.\mathrm{Al}^{3+}\right)$.

\section{ACKNOWLEDGMENTS}

The authors thank Financiadora de Estudos e Projetos (FINEP) for financial support, through CTMINERAL Project "Caracterização de depósitos minerais em distritos mineiros da Amazônia", managed by Agência para o Desenvolvimento da Indústria Mineral do Brasil (ADIMB), in collaboration with the Departamento Nacional de Produção Mineral (DNPM); Conselho Nacional de Desenvolvimento Científico e Tecnológico (CNPq) through CT/MINERAL Project "Modelos genético e prospectivo do distrito mineiro de Pitinga" supported the final phase of this work. They also thank to Fundação de Amparo à Pesquisa do Estado do Rio Grande do Sul/Programa de Apoio a Núcleos de Excelência (CNPq-FAPERGS/PRONEX) Project 04/0825-3, for the financial support and CNPq, for the research grants to Artur Cezar Bastos Neto and Milton Luiz Laquintinie Formoso, 306591/2006-5 and 308498/ 2005-4 respectively.

\section{RESUMO}

Este trabalho enfoca a geoquímica de elementos terras raras (ETR) e de Y no minério criolítico disseminado, no depósito criolítico maciço e na fluorita associada na mina Pitinga. As assinaturas de ETR na criolita e fluorita são similares àquelas do granito Madeira. Os maiores valores de $\Sigma$ ETR são encontrados na criolita magmática disseminada (677 a 1.345 ppm); $\Sigma$ ETR é menor na criolita maciça, com valores médios de $10,3 \mathrm{ppm}, 6,66 \mathrm{ppm}$ e $8,38 \mathrm{ppm}$, respectivamente, nos tipos de criolita nucleada, caramelo e branca. A fluorita magmática disseminada apresenta os valores mais altos de $\Sigma$ ETR (1.708 e $1.526 \mathrm{ppm}$ ), contrastando com a fluorita de veio tardio (34,81 ppm). A concentração de Y é maior na fluorita disseminada e na criolita magmática. As evoluções de diversos parâmetros ( $\Sigma$ ETR, ETRL/ETRP, Y) podem ser seguidas através dos sucessivos estágios de evolução dos albita granitos e mineralização associada. Os dados de ETR indicam que o depósito criolítico maciço foi formado por, e o minério disseminado enriquecido por (formação adicional criolita disseminada hidrotermal), fluidos hidrotermais residuais do albita granito. A presença do efeito tetrad não é bem definida, embora as criolitas maciças nucleada, caramelo e branca apresentem algumas evidências deste efeito.

Palavras-chave: criolita, ETR, Y, Pitinga, Amazônia.

\section{REFERENCES}

Almeida FFM, Hasui Y, BRito-Neves BB and Fuck RA. 1981. Brazilian structural provinces: An introduction. Earth Sci Rev 17: 1-29.

ANDERS E AND GREVESSE N. 1989. Abundances of elements: meteoritic and solar. Geochim Cosmochim Acta, 53: $197-214$.

BAU U AND DULSKI P. 1995. Comparative study of yttrium and rare-earth element behaviors in fluorine-rich hydrothermal fluids. Contrib Mineral Petrol 119: 213-223.

BLAXLAND AB. 1976. Rb-Sr isotopic evidence for the age and origin of the Ivigtut granite and associa cryolite body, South Greenland. Econ Geol 71: 864-869.

Bowden P And Kinnaird JA. 1984. Geology and mineralization of the Nigerian Anorogenic Ring Complexes. Geologisches Jahrbuch, reihe B, heft 56: 3-65.

Costi HT. 2000. Petrologia de granitos alcalinos com alto flúor mineralizados em metais raros: o exemplo do Albitagranito da Mina Pitinga, Amazonas, Brasil. Curso de PósGraduação em Geologia e Geoquímica da Universidade Federal do Pará. Tese de Doutorado, 345 p.

Costi HT, Dall'Agnol R and Moura CAV. 2000. Geology and $\mathrm{Pb}-\mathrm{Pb}$ Geochronology of Paleoproterozoic Volcanic and Granitc rocks of Pitinga Province, Amazonian Craton, Northern Brazil. Int Geol Rev 42: 832-849.

Chang Lly, Howie RA And Zussman J. 1996. RockForming Minerals, vol. 5B: Non Silicates. Longman, Essex, 383 p.

Ferron JMTM, Bastos Neto AC, Lima eF, Costi HT, Moura CAV, Prado M ANd Galarza MA. 2006. Geologia e geocronologia $\mathrm{Pb}-\mathrm{Pb}$ de rochas graníticas e vulcânicas ácidas a intermediárias da Província Pitinga (AM). Rev Bras Geocienc 36: 499-512.

GliUK DS AND ANFILOgOV NV. 1973. Phase equilibria in the system granite- $\mathrm{H}_{2} \mathrm{O}-\mathrm{HF}$ at a pressure of $1000 \mathrm{~kg} / \mathrm{cm}^{2}$. Geochem Int 10: 321-325. 
Horbe MA, Horbe AC, TeIXeira JT And Costi HT. 1985. Granito Madeira: petrologia, petroquímica e mineralizações. II Simpósio de Geologia da Amazônia, Anais... Belém, SBG/NM 3: 284-320.

IRBER W. 1999. The lanthanide tetrad effect and its correlation with $\mathrm{K} / \mathrm{Rb}, \mathrm{Eu} / \mathrm{Eu}$ *, $\mathrm{Sr} / \mathrm{Eu}, \mathrm{Y} / \mathrm{Ho}$, and $\mathrm{Zr} / \mathrm{Hf}$ of evolving peraluminous granite suites. Geochim Cosmochim Acta 63 (3/4): 489-508.

Kinnaird JA, Bowden P, IVEr RA AND OdLing NWA. 1985. Mineralogy, geochemistry and mineralization and the Ririway complex, northern Nigeria. J Afr Earth Sci 3: $185-222$.

KovAlENKO VI. 1977. The reactions between granite and aqueous hydrofluoric acid in relation to the origin of fluorine-bearing granites. Geochem Int 14: 108-118.

LENHARO SLR. 1998. Evolução magmática e modelo metalogenético dos granitos mineralizados da região de Pitinga, Amazonas, Brasil: Tese de Doutorado, Escola Politécnica da Universidade de São Paulo, Brazil, 290 p.

LONDON D. 1989. Litophile rare element concentration in silic rocks: the alkaline trend in granitic systems. Geol Assoc Can - Mineral Assoc, Program Abstr 14, A21.

MANNING DAC. 1981. The effect of Fluorine on liquidus phase relationships in the system Qz-Ab-Or with excess water at $1 \mathrm{~kb}$. Contrib Mineral Petr 76: 206-215.

MANNING DAC AND PichaVAnt M. 1988. Volatiles and their bearing on the behaviour of metals in granitic systems. In: TAYLOR RP AND STRONG DF (Eds.), Recent advances in the geology of granite-related mineral deposits. Can Inst Min Metall, Special Volume 39: 13-24.

Méary A, Touray JC, Galland D And JebraK M. 1985. Interprétation de l'anomalie en europium des fluorines hydrotermales. Données de la RPE. Aplication au gite de fluorine de Montroc (Tarn). Chem Geol 48: 115124.

Minuzzi ORR, Bastos Neto AC, Pereira VP ANd FLORES JAA. 2006. O depósito criolítico maciço e o minério disseminado de criolita da mina Pitinga (Amazonas, Brasil). Rev Bras Geocienc 36: 104-123.

PAUly H AND BAILEY JC. 1999. Genesis and evolution of the Ivigtut cryolite deposit, SW Greenland. Meddelelser Grøland, Copenhagen, Geoscience, 37: 60 p.
PichaVant M And Manning DAC. 1984. Petrogenesis of tourmaline granites and topaz granites: the contribution of experimental data. Phys Earth Planet Interiors 35: 31-50.

Pichavant M, Boher M, Stenger JF, Aissa M And Charoy B. 1987. Relations de phases de granites de Beauvoir à 1 et $3 \mathrm{kbar}$, en conditions de saturation en $\mathrm{H}_{2} \mathrm{O}$. Geol Fr 2-3: 77-86.

Pires AC, Bastos Neto AC, Pereira VP, Botelho NF AND MINUZZI ORR. 2006. Gargarinita-(y) com polimorfo de fluocerita: provável caso de formação de um novo mineral por exsolução de ETRL a partir de fluoreto de ETRLP (mina Pitinga - AM). Rev Bras Geocienc 36: 155-164.

Santos Jos, Hartmann LA, Gaudette HE, Groves Di, MCNaughton NJ and Fletcher I. 2000. A new understanding of the provinces of the Amazon craton based on integration of field mapping and $\mathrm{U}-\mathrm{Pb}$ and SmNd geocronology: Gondwana Res 4: 453-488.

SVERJENSKY DA. 1984. Europium redox equilibria in aqueous solution - Earth and Planet Sci Lett 67: 70-78.

TASSINARI CCG AND MACAMBIRA MJB. 1999. Geochronological provinces of the Amazonian Craton. Episodes. 223: $174-182$.

TeIXeIra JT, Costi HT, Minuzzi ORR AND SOARES EAA. 1992. Depósitos primários de criolita, cassiterita, xenotímio e columbita em apogranito - mina do Pitinga (AM). In: ANAIS DO XXXVII CONGRESSO BRASILEIRo De Geologia, São Paulo, SBG 1: 212-213.

TUTTLE OF AND BOWEN NL. 1958. Origin of granite in the light of experimental studies in the system $\mathrm{NaAlSi}_{3} \mathrm{O}_{8}$ $\mathrm{KalSi}_{3} \mathrm{O}_{8}-\mathrm{SiO}_{2}-\mathrm{H}_{2} \mathrm{O}$. Geol Soc Am Mem 74: 153.

WEIDNER JR AND MARTIN RF. 1987. Phase equilibria of a fluorine-rich leucogranite from the St. Austell pluton, Cornwal. Geochim Cosmochim 51: 1591-1597.

Wyllie PJ And Tuttle OF. 1961. Experimental investigation of silicate systems containing two volatile components. Part II. The effects of $\mathrm{NH}_{3}$ and $\mathrm{HF}$, in addition to $\mathrm{H}_{2} \mathrm{O}$ on the melting temperatures of albite and granite. Am J Sci 259: 128-143.

Xiong XL, ZhaO AH, Zhu JC And RaO B. 1999. Phase relations in albite granite- $\mathrm{H}_{2} \mathrm{O}-\mathrm{HF}$ system and their petrogenetic applications. Geochem J 33: 199-214. 